Jurnal Biologi dan Pembelajarannya, Vol 7 No 1, April 2020. Pp: 28-32

e-ISSN: $2406-8659$

\title{
SKRINING FITOKIMIA FAMILIA PIPERACEAE
}

\author{
${ }^{1}$ Afifah Rukmini, ${ }^{1}$ Danang Hadi Utomo, ${ }^{2}$ Ainun Nikmati Laily \\ ${ }^{1}$ Jurusan Biologi UIN Maulana Malik Ibrahim Malang \\ 2 Jurusan Tadris Biologi IAIN Tulungagung \\ Email: lailynun@gmail.com
}

\begin{abstract}
Abstrak
Indonesia merupakan negara dengan kekayaan alam yang melimpah, hampir segala jenis tumbuhan dapat tumbuh di negara ini. Saat ini, penggunaan bahan herbal telah banyak dikembangkan. Sejalan dengan hal tersebut, taksonomi modern mensyaratkan adanya pendugaan senyawa kimia dalam suatu tumbuhan selain kajian morfologinya. Salah satu familia yang berpotensi sebagai bahan obat dan telah banyak dimanfaatkan adalah Piperaceae. Penelitian ini merupakan penelitian awal yang bertujuan untuk mendeteksi senyawa bahan obat pada dua ekstrak spesies anggota Piperaceae, yakni Piper betle dan Peperomia pellucida. Ekstraksi dilakukan dengan metode maserasi menggunakan pelarut etonol 96\%. Pemeriksaan terhadap daun sirih (Piper betle L.) positif mengandung steroid, alkoloid, flavanoid, dan minyak atsiri. Pemeriksaan terhadap daun sirih air (Peperomia pellucida L. Kunth) positif mengandung alkaloid, flavonoid, terpenoid, minyak atsiri, dan tanin. Hasil penelitian ini lebih lanjut dapat digunakan sebagai bahan penelitian dalam bidang taksonomi tumbuhan maupun penemuan bahan obat.
\end{abstract}

Kata kunci-Piperaceae, Skrining, Fitokimia

\section{PENDAHULUAN}

Kekayaan alam yang dimiliki oleh bangsa Indonesia sangat melimpah, khususnya kekayaan floranya yang memiliki bermacam-macam tumbuhan. Tumbuhan tersebut mempunyai manfaat yang besar bagi kehidupan manusia, terutama sebagai sumber makanan maupun obat-obatan. Sebagai sumber makanan, tidak bisa dipungkiri bahwa tumbuh-tumbuhan merupakan bahan pokok yang wajib ada dan menjadi sumber makanan utama bagi bangsa Indonesia. Sedangkan sebagai sumber obat-obatan, kekayaan flora di Indonesia sebenarnya sudah cukup banyak dimanfaatkan oleh nenek moyang bangsa kita untuk mengobati berbagai macam penyakit. Berbagai jenis tumbuhan mengandung senyawa metabolit sekunder, Senyawa metabolit sekunder yang terdapat dalam tumbuhan merupakan zat bioaktif yang berkaitan dengan kandungan kimia dalam tumbuhan, sehingga sebagian tumbuhan dapat digunakan sebagai bahan obat.

Spesies anggota Familia Piperaceae banyak dimanfaatkan masyarakat dalam pengobatan. Adalah daun sirih (Piper betle L.) merupakan tanaman yang banyak dijumpai di sekitar kita dan pada komposisi jamu tradisional. Simplisia daun sirih biasanya dipergunakan sebagai salah satu komponen utama dalam obat keputihan [1]. Sementara itu dalam anggota familia yang sama masyarakat pada umumnya belum mengetahui khasiat dan manfaat dari tanaman sirih air (Peperomia pellucida L. Kunth). Tumbuhan sirih air merupakan tumbuhan gulma yang biasanya tumbuh liar di tempat-tempat yang lembab dan bergerombol. Tumbuhan Sirih air (Peperomia pellucida L. Kunth) secara tradisional telah dimanfaatkan dalam mengobati beberapa penyakit, seperti asam urat, bisul, jerawat, radang kulit, penyakit ginjal, dan sakit perut [2]. Masyarakat di beberapa daerah di Sulawesi Utara telah juga memanfaatkan tanaman ini untuk penurun kolesterol darah [3].

Pengembangan obat tradisional diusahakan agar dapat sejalan dengan pengobatan modern. Berbagai penelitian dan pengembangan yang memanfaatkan kemajuan teknologi juga dilakukan sebagai upaya peningkatan mutu dan keamanan produk yang diharapkan dapat lebih meningkatkan kepercayaan terhadap manfaat obat tradisional juga di dukung oleh Peraturan Menteri Kesehatan Republik Indonesia, tentang fitofarmaka, yang berarti diperlukan mutu simplisia yang akan digunakan untuk bahan baku obat atau sediaan galenic [4].

Skrining fitokimia merupakan tahap pendahuluan dalam suatu penelitian fitokimia yang bertujuan untuk memberikan gambaran tentang golongan senyawa yang terkandung dalam tanaman yang sedang diteliti. Penemuan obat-obat baru sangat penting untuk tiap-tiap pemerintah daerah di dalam negeri pada waktu ini. Salah satu sumber alam yang berpotensi memiliki kandungan bioaktif yang dapat berfungsi sebagai obat adalah sumberdaya hayati khususnya tanaman anggota Familia Piperaceae ini. Oleh karena itu, untuk meningkatkan nilai guna anggota Familia Piperaceae di dalam negeri perlu dilakukan penelitian lebih lanjut dan 
Jurnal Biologi dan Pembelajarannya, Vol 7 No 1, April 2020. Pp: 28-32

e-ISSN: $2406-8659$

berkesinambungan dalam rangka menemukan senyawa-senyawa bioaktif selanjutnya dapat diproduksi menjadi obat dalam industri farmasi [5].

Pengujian senyawa bioaktif atau skrining fitokimia terdapat beberapa metode ekstraksi yang satu diantaranya yaitu metode maserasi, metode maserasi ini merupakan metode ekstraksi yang sederhana. Dikatakan sederhana karena metode maserasi ini menggunakan alat-alat yang sederhana pula. Menurut Indraswari (2008) metode maserasi dilakukan dengan cara merendam serbuk simplisia dalam cairan penyari [6]. Cairan penyari akan menembus dinding sel dan masuk ke dalam rongga sel yang mengandung zat aktif dan zat aktif akan larut.

Baik sirih (Piper betle L.) maupun sirih air (Peperomia pellucida L. Kunth) adalah anggota Piperaceae yang berpotensi tinggi digunakan sebagai bahan baku obat dan mudah ditemukan di lingkungan masyarakat. Sejalan dengan hal tersebut, taksonomi modern mensyaratkan adanya pendugaan senyawa kimia dalam suatu tumbuhan selain kajian morfologinya. Maka tujuan penelitian ini adalah melalukan skrining fitokimia terhadap dua anggota Familia Piperaceae yakni sirih (Piper betle L.) dan Sirih air (Peperomia pellucida L. Kunth) dengan menggunakan metode maserasi pada simplisia daun dengan pelarut etanol $96 \%$. Hasil penelitian ini lebih lanjut dapat digunakan sebagai bahan penelitian lanjut dalam bidang taksonomi tumbuhan maupun penemuan bahan obat.

\section{METODE PENELITIAN}

1. Sampel daun sirih (Piper betle L.)

a. Preparasi sampel

Sampel daun sirih (Piper betle L.) disiapkan sebanyak $1 \mathrm{~kg}$. Selanjutnya Sampel dicuci dan dipotong berukuran sedang kemudian dikeringkan menggunakan oven selama 24 jam dengan suhu $60^{\circ} \mathrm{C}$, setelah kering maka sampel berupa simplisia diblender hingga menjadi halus kemudian diayak dengan ayakan 60 mesh.

b. Ekstraksi sampel

Sebanyak 70gram simplisia di ekstraksi menggunakan pelarut etanol $96 \%$. Ekstraksi dilakukan dengan cara maserasi $2 \times 24 \mathrm{jam}$. Hasil ekstraksi Kemudian diuapkan dengan rotary vacuum evaporator pada suhu $40{ }^{\circ} \mathrm{C}$ sampai menjadi endapan kental atau seperti pasta.

c. Uji Fitokimia

1) Uji Alkaloid

Uji alkaloid dilakukan dengan 0,5gram ekstrak daun Sirih air (dan ditambahkan 8 tetes $\mathrm{H}_{2} \mathrm{SO}_{4} 2 \mathrm{~N}$ dan ditetesi dengan penguji Dragendroff sebanyak 3 tetes. Hasilnya ditandai dengan endapan Jingga pada reagen Dragendroff [7].

2) Uji Flavonoid

Uji flavonoid dilakukan dengan 0,5gram ekstrak daun Sirih dan ditetesi dengan $\mathrm{H}_{2} \mathrm{SO}_{4}$ pekat. Hasil ditunjukkan dengan munculnya warna hijau kekuningan atau hijau kehitaman [8].

3) Uji Saponin

Ekstrak 0,5gram ditambahkan $10 \mathrm{ml}$ aquades hangat, kemudian dikocok selama 30 detik. Hasilnya ditandai dengan adanya buih pada larutan.

4) Terpenoid

Uji terpenoid dilakukan dengan mereaksikan 0,5 gram ekstrak daun Sirih air dengan 10 tetes $\mathrm{H}_{2} \mathrm{SO}_{4}$ melalui dinding tabung. Hasil di tunjukkan dengan terbentuknya warna hijau dan biru [7].

5) Minyak Atsiri

Skrining fitokimia minyak atsiri dilakukan dengan cara ekstrak kental 0,5 gram diencerkan dengan pelarut $1 \mathrm{~mL}$ kemudian atau dipanaskan di hotplate di atas gelas arloji hingga diperoleh residu. Hasil positif minyak atsiri ditandai dengan bau khas yang dihasilkan oleh residu tersebut [9].

6) Uji Tanin

Ekstrak 0,5 gram ditambahkan $\mathrm{FeCl}_{3} 1 \%$, adanya tannin ditandai dengan terbentuknya hijau kebiruan [10].

\section{HASIL DAN PEMBAHASAN}

Hasil uji skrining fitokimia terhadap ekstrak etanol $96 \%$ daun sirih air (Piper betle L.) menunjukkan bahwa ekstrak mengandung steroid, alkoloid, flavanoid dan minyak atsiri. Berikut pada Tabel 1. Dijelaskan pengamatan pada skrining fitokimia daun sirih ( Piper betle L.). 
Jurnal Biologi dan Pembelajarannya, Vol 7 No 1, April 2020. Pp: 28-32

e-ISSN: $2406-8659$

Tabel 1. Data skrining fitokimia daun sirih ( Piper betle L.)

\begin{tabular}{|cccl|}
\hline Skrining Fitokimia & Reagen & Hasil & \multicolumn{1}{c|}{ Keterangan } \\
\hline Saponin & Aquades & - & Mengandung busa \\
\hline Steroid & $\mathrm{H}_{2} \mathrm{SO}_{4}$ & + & Warna kuning tua \\
\hline Alkoloid & Dragendroff & + & Warna kuning kehitaman \\
\hline Flavanoid & $\mathrm{H}_{2} \mathrm{SO}_{4}$ & + & Warna merah bata \\
\hline Minyak atsiri & $\begin{array}{c}\text { Etanol } 96 \%+ \\
\text { dipanaskan }\end{array}$ & + & Mengandung minyak dan berbau khas \\
\hline
\end{tabular}

Data yang diperoleh dalam tabel di atas dilengkapi dengan gambar yang tampak pada sampel daun sirih (Piper betle L.) pada saat dilakukan skrining fitokimia.

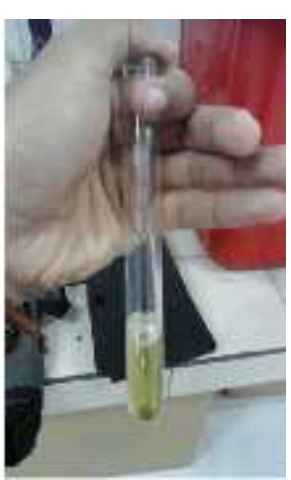

Saponin

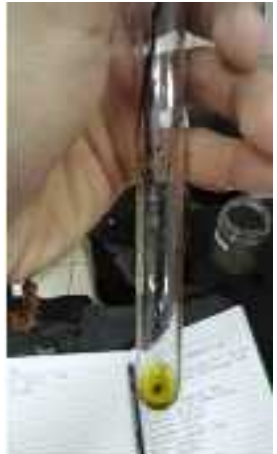

Steroid

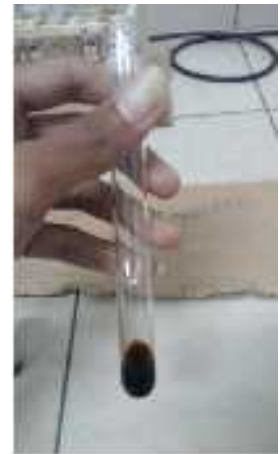

Alkoloid

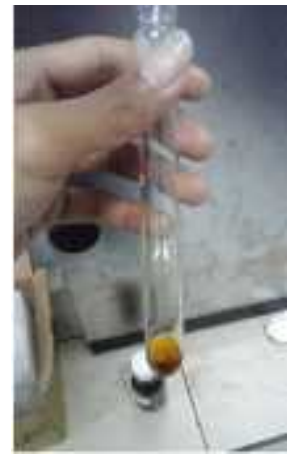

Flafonoid

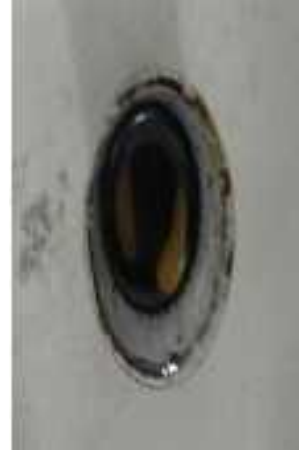

Minyak atsiri

Gambar 1. Gambar skrining fitokimia sirih (Piper betle L.)

Sementara itu, hasil uji skrining fitokimia pada ekstrak etanol $96 \%$ daun sirih air (Peperomia pellucida L. Kunth) menunjukkan bahwa ekstrak positif mengandung flavonoid, minyak atsiri, alkaloid, tanin, dan triterpenoid.

Berikut pada Tabel 2. Dijelaskan pengamatan pada skrining fitokimia daun sirih air (Peperomia pellucida L. Kunth).

Tabel 2. Data skrining fitokimia daun sirih air (Peperomia pellucida L. Kunth)

\begin{tabular}{|cccl|}
\hline Skrining Fitokimia & Reagen & Hasil & \multicolumn{1}{c|}{ Keterangan } \\
\hline Alkaloid & Dragendrof & + & Terbentuknya sedimen merah \\
\hline Flavonoid & $\mathrm{H}_{2} \mathrm{SO}_{4}$ & + & $\begin{array}{l}\text { Terjadi perubahan warna hijau pekat } \\
\text { (hijau kehitaman) }\end{array}$ \\
\hline Saponin & $\mathrm{Aquades}$ & - & Tidak terdapat Buih \\
\hline Terpenoid & $\mathrm{H}_{2} \mathrm{SO}_{4}$ & + & Terjadi perubahan warna hijau \\
\hline Tanin & $\mathrm{FeCl}_{3} 1 \%$ & + & Hijau kebiruan \\
\hline Minyak atsiri & $\begin{array}{c}\text { Etanol 96\%+ } \\
\text { dipanaskan }\end{array}$ & + & Tercium bau yang khas \\
\hline
\end{tabular}

Berdasarkan kepolaran dan kelarutan, senyawa yang bersifat polar akan mudah larut dalam pelarut polar, sedangkan senyawa nonpolar akan mudah larut dalam pelarut nonpolar [11]. Hasil pemeriksaan saponin pada sampel daun sirih didapatkan hasil yang negatif, busa terbentuk tidak begitu nampak, demikian pula yang terjadi pada sirih air tidak terbentuk busa atau buih pada sampel uji. Saponin pada umumnya berada dalam bentuk glikosida sehingga cenderung bersifat polar [12]. Saponin adalah senyawa aktif permukaan yang dapat menimbulkan busa jika dikocok dalam air. Hal tersebut terjadi karena saponin memiliki gugus polar dan non polar yang akan membentuk misel. Pada saat misel terbentuk maka gugus polar akan menghadap ke luar dan gugus nonpolar menghadap ke dalam dan keadaan inilah yang tampak seperti busa [13].

Data yang diperoleh dalam tabel di atas dilengkapi dengan gambar yang tampak pada sampel daun sirih air (Peperomia pellucida L. Kunth) pada saat dilakukan skrining fitokimia. 

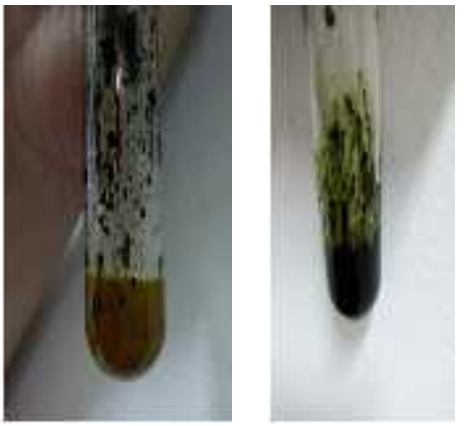

Alkaloid

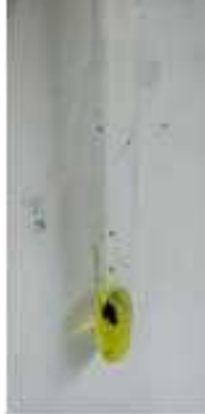

Saponin

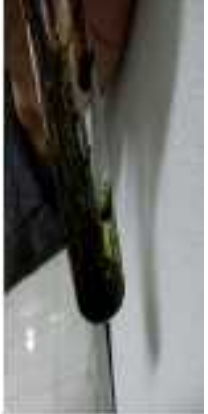

Triterpenoid

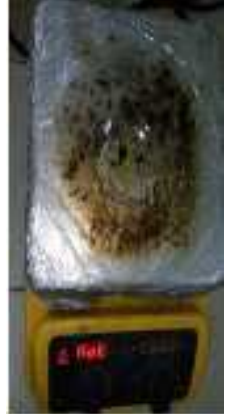

Minyak atsiri

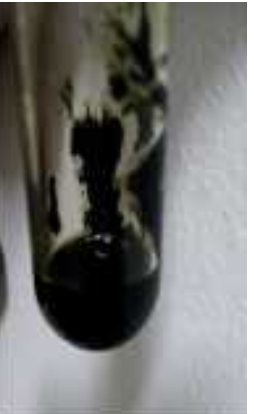

Tanin

Gambar 2. Gambar skrining fitokimia sirih air (Peperomia pellucida L. Kunth)

Uji steroid terhadap sampel daun sirih menunjukkan hasil positif dengan penambahan $\mathrm{H}_{2} \mathrm{SO}_{4}$ karena berwarna kuning tua hal ini terjadi karena mengandung sikloartenol yang merupakan senyawa triterpen. Uji steroid ini tidak diujikan pada sirih air. Uji flavanoid terhadap sampel daun sirih menunjukkan hasil yang positif dengan penambahan $\mathrm{H}_{2} \mathrm{SO}_{4}$ menghasilkan warna merah bata, flavanoid adalah suatu kelompok senyawa fenol, senyawa ini bertanggung jawab terhadap zat warna merah, ungu, biru, dan sebagai zat warna kuning pada tumbuhan. Uji flavonoid terhadap sirih air didapatkan hasil yang positif pula yakni dengan adanya perubahan warna hijau kehitaman atau hijau pekat. Flavonoid umumnya lebih mudah larut dalam air atau pelarut polar dikarenakan memiliki ikatan dengan gugus gula [13].

Pengujian alkaloid terhadap sampel daun sirih dan sirih air didapatkan hasil yang positif dengan menggunakan larutan Dragendroff, ditandai dengan adanya sedimen merah. Alkaloid dapat tertarik pada pelarut etanol karena senyawa alkaloid bersifat polar [13]. Reaksi positif yang terjadi pada uji alkaloid adalah terbentuknya endapan jingga pada pereaksi dragendorff, hal tersebut terjadi karena adanya reaksi penggantian ligan. Alkaloid yang memiliki atom nitrogen yang mempunyai pasangan elektron bebas dapat mengganti ion ion dalam pereaksi-pereaksi tersebut.

Pengujian senyawa tanin terhadap sampel sirih air didapatkan hasil yang positif dengan adanya perubahan warna hijau kebiruan. Golongan tanin yang merupakan senyawa fenolik cenderung larut dalam air sehingga cenderung bersifat polar [7]. Pengujian tanin menunjukkan bahwa tanin yang terkandung di dalam ekstrak etanol merupakan tanin kondensasi karena terbentuk warna hijau kehitaman setelah ditambahkan dengan $\mathrm{FeCl}_{3}$ [13]. Pemeriksaan triterpenoid didapatkan hasil yang positif dengan adanya perubahan warna hijau. Kemampuan senyawa untuk membenrtuk warna $\mathrm{H}_{2} \mathrm{SO}_{4}$ pekat dalam pelarut asam asetat anhidrid [13]. Pemeriksaan keberadaan senyawa tanin dan terpenoid dalam penelitian ini diujikan pada sampel daun sirih air.

\section{SIMPULAN}

Telah dilakukan skrining fitokimia terhadap dua anggota Familia Piperaceae. Pemeriksaan terhadap daun sirih (Piper betle L.) positif mengandung steroid, alkoloid, flavanoid dan minyak atsiri. Pemeriksaan terhadap daun sirih air (Peperomia pellucida L. Kunth) positif mengandung alkaloid, flavonoid, terpenoid, minyak atsiri, dan tanin.

\section{SARAN}

\section{UCAPAN TERIMA KASIH}

Ucapan terima kasih kami sampaikan kepada UIN Maulana Malik Ibrahim Malang yang telah atas fasilitas yang diberikan.

\section{DAFTAR PUSTAKA}

[1] Agusta, A., 2000, Minyak Atsiri Tumbuhan Tropika Indonesia, ITB, Bandung.

[2] Hariana, Arief. 2006. Tumbuhan Obat dan Khasiatnya Seri 3. Jakarta : Penerbit Swadaya. 
Jurnal Biologi dan Pembelajarannya, Vol 7 No 1, April 2020. Pp: 28-32

e-ISSN: $2406-8659$

[3] Sitorus, E,. L. I. Momuat, dan D. G. Katja. 2013. Aktifitas Antiokidan Tumbuhan Sirih air. Universitas Sam Ratulangi. Manado.

[4] BPOM RI. 2005. Peraturan Kepala Badan Pengawasan Obat Dan Makanan Republik Indonesia Nomor Hk 00.05.41.1384 Tentang Kriteria Dan Tata Laksana Pendaftaran Obat Tradisional, Obat Herbal Terstandar Dan Fitofarmaka. Jakarta :Kepala BPOM.

[5] Markham, K.R. 1988. Techniques of Flavonoid Identification. London: Academic Pr.

[6] Indraswari, Arista. 2008. Optimasi pembuatan ekstrak daun dewandaru (Eugeni uniflora L.) Menggunakan Metode Maserasi Dengan Parameter Kadar Total Senyawa Fenolik Dan Flavonoid. Skripsi Universitas Muhammadiyah Surakarta.

[7] Harborne, J.B. (1987). Metode Fitokimia: Penuntun Cara Modern Menganalisis Tumbuhan, Terbitan Kedua. Bandung : Penerbit ITB.

[8] Arifin. 2006. Standarisasi Ekstrak Etanol Daun Eugenia Cumini Merr. J. Sains Tek. Farmasi.

[9] Ciulei, J. 1984. Metodology for Analysis of Vegetables and Drugs. Bucharest: Faculty of Pharmacy. Pp. 11-26.

[10] Atmoko, Tri. 2009. Uji Toksisitas dan Skrining Fitokimia Ekstrak Tumbuhan Sumber Pakan Orangutan Terhadap Larva Artemi salina L. Jurnal Penelitian Hutan dan Konservasi Alam Vol. 6 No.1.

[11] Depkes RI. 2000. Parameter Standar Umum Ekstrak Tumbuhan Obat, Cetakan Pertama. Jakarta: Direktorat Jendral Pengawasan Obat dan Makanan.

[12] Robinson, T. 1991. Kandungan Organik Tumbuhan Tingkat Tinggi. Bandung: Penerbit ITB

[13] Sangi, M., M.R.J. Runtuwene., H.E.I. Simbala., V.M.A. Makang. 2008. Analisis Fitokimia Tumbuhan Obat di kabupaten Minahasa Utara. Chem. Prog. 1(1):47-53. 